\title{
Radiation Nephritis: Anti-inflammatory Effect of Dexamethasone in Adult Wistar Rats (Rattus norvegicus)
}

\author{
Nefritis por Radiación: Efecto Anti-inflamatorio de la Dexametasona en Ratas Wistar Adultas (Rattus norvegicus)
}

"Owoeye, O.; **Malomo, A. O.; ****Elumelu, T. N.; "Salami, A. A.; "Osuagwu, F. C.;

****Akinlolu, A. A.; ****Adenipekun, A. \& "Shokunbi, M. T.

OWOEYE, O.; MAlOMO, A. O.; ElUMElU, T. N.; SAlAMI, A. A.; OSUAGWU, F. C.; AKINLOLU, A. A.; ADENIPEKUN, A. \& SHOKUNBI, M. T. Radiation nephritis: anti-inflammatory effect of dexamethasone in adult Wistar rats (Rattus novergicus). Int. J. Morphol., 26(1):69-74, 2008.

SUMMARY: The anti-inflammatory effect of dexamethasone on the irradiated kidneys of adult Wistar rats (Rattus norvegicus) was studied. Eighteen adult Wistar rats were, after acclimatization, randomly divided into 3 groups of 6 animals per group. The control group had normal saline, receiving neither drugs nor radiation. The second group received normal saline and radiation. The third group received pretreatment with dexamethasone at $1 \mathrm{mg} / \mathrm{kg}$ body weight/day for 2 days followed by radiation. Radiation was delivered to the animals as a single fraction of 2.5 Gy of gamma rays from Cobalt-60 source, using an AECL Theatron 780-C Teletherapy machine. After exposure to the different interventions, the animals were sacrificed on the $14^{\text {th }}$ post-irradiation day and the kidneys dissected out from each animal. The renal tissues were subjected to histological processing, and then studied using an eyepiece objective ruler calibrated with a $2 \mathrm{~mm}$ stage micrometer for histomorphometric studies. The result of the study showed that all irradiated animals suffered weight loss by the $14^{\text {th }}$ day post-irradiation $(\mathrm{p}<0.05)$ irrespective of the additional treatment with dexamethasone and this was statistically significant. Histomorphometry showed that the maximum width of the glomerular capsule was significantly greater in the radiation groups than in the control at $\mathrm{p}<0.05$. The maximal glomerular diameter was significantly greater in irradiated animals compared with the control animals at $\mathrm{p}<0.05$. The outcome of this study showed that the intraperitoneal administration of dexamethasone at $1 \mathrm{mg} / \mathrm{kg}$ body weight/day for 2 days prior to treatment with irradiation did not prevent weight loss nor ameliorate the swelling of the nephrons resulting from the effect of radiation injury to the Wistar rat.

KEY WORDS: Radiation; Nephrons; Glomerulus; Nephritis; Anti-inflammatory; Kidney.

\section{INTRODUCTION}

The urinary system is the principal organ system responsible for water and electrolyte homeostasis. It provides the mechanism by which excess water and electrolytes are eliminated from the body, it also excretes toxic metabolic waste products, the end products of these processes being urine production (Young \& Heath, 2000). In addition, detoxification and elimination of drugs, control of red blood cell mass through production of erythropoietin, endocrine control of mineral metabolism, and maintenance of acid base balance are other important functions of the kidneys (Salako, 2005).

The kidneys contain the nephrons, regarded to be the functional unit of the urinary system. Histologically, the nephron consists of renal corpuscles (glomeruli and glomerular capsule) and renal tubules. The nephrons perform the osmoregulation and excretion through the processes of filtration, selective reabsorption and secretion of some excretory products directly from the blood into the filtrate. To performing these functions, the kidneys possess the glomerular filtration barrier, which consists of: (1) the capillary endothelial inner layer, (2) the unusually thick glomerular capillary basement membrane, and (3) the podocyte layer (Stevens \& Lowe, 1999).

Medically, ionizing radiation may be used as the sole treatment or as adjuvant to chemotherapy or surgical

* Department of Anatomy, College of Medicine, University of Ibadan, Ibadan, Nigeria.

** Department of Surgery, College of Medicine, University of Ibadan, Ibadan, Nigeria.

*** Department of Radiotherapy, College of Medicine, University of Ibadan, Ibadan, Nigeria.

**** Department of Anatomy, Faculty of Basic Medical Sciences, Olabisi Onabanjo University, Ago-Iwoye, Nigeria. 
management of neoplasia of different parts of the human body e.g. breast, cervix, bones, kidneys (Aunapuu et al., 2003) and lungs, amongst others. Total body irradiation (TBI) is also involved in preparation of patients as part of the conditioning regime before bone marrow transplantation.

Irradiation of the kidney may occur during TBI, which is a form of direct injury, or as a consequence of irradiation of nearby structures, thus causing radiation nephritis. Cohen (2002), defined radiation nephritis as kidney injury and impairment of its function by ionizing radiation, which can occur after irradiation of one or both kidneys. The kidneys are highly radiosensitive organs, but radiation-induced injury occurs in proportion to the radiation dose and volume of renal tissues exposed, and this may lead to renal failure.

Investigators have reported the ameliorative effect of drugs on radiation nephritis. These include the work on acetylsalicylic acid (ASA) by Verheij et al. (1995); Cohen et al. (1997), who used Captopril; and Moulder et al. (1993), who experimented with Enapril. Captopril and Enapril are angiotensin converting enzyme inhibitors (ACEI). The results of these studies showed that these drugs have ameliorative effect on the pathology of radiation nephritis.

Dexamethasone (9a-fluoro-16a-methyl-prednisolone), a synthetic glucocorticoid with potent anti-inflammatory activity has the ability to stabilize lysosomal membranes (Guyton \& Hall, 2000). The potency of its antiinflammatory activity has been quantified to be 25 to 30 times compared with hydrocortisone (Haynes, 1992; Ganong, 2001). All glucocorticoids have the capacity to prevent or suppress the development of the manifestations of inflammatory response whether the inciting agent is radiation, mechanical, chemical, infectious, or immunological (Haynes). Glucocorticoids also appear to stabilize lysosomal membranes in affected cells by preventing the release of vasoactive kinins and destructive enzymes (Guyton \& Hall), an important fact since lysosomes are the most radiosensitive organelles (Schull, 1995). Lysosomal membrane damage may lead to disruption and subsequent lysis via lipid peroxidative attack by free radicals in radiation injury.

This study was set out to determine the antiinflammatory effect of dexamethasone on some of the established pathologic manifestations of radiation nephritis, especially the swelling of the glomeruli. Our attention in this study was focused on the histomorphological changes in kidney tissue after radiation of $2.5 \mathrm{~Gy}$, given as a single fraction without renal shielding.

\section{MATERIAL AND METHOD}

Experimental animals. Eighteen adult Wistar rats (Rattus norvegicus) were obtained from the Central Animal House of the College of Medicine, University of Ibadan, Nigeria. Their weights ranged between $170 \mathrm{~g}-190 \mathrm{~g}$. They were randomly divided into three groups of 6 animals per group and then allowed 5 days to acclimatize to animal room condition. All animals were allowed free access to standard rat pellets obtained from Ladokun Livestock Feeds Limited, Ibadan, Nigeria, and tap water ad libitum at room temperature. Weight measurements were made during the experiments using a Swiss Microwa balance type 7720 . All procedures on animal handling conformed to the guidelines on ethical use of animals in research and relevant local guidelines.

\section{Animal Groupings}

Group A $(n=6)$ : the control group animals that had intraperitoneal sham injection of normal saline only at an average of $0.04 \mathrm{ml} /$ rat per day, for 2 days.

Group B $(n=6)$ : the animals were randomized to receive 2.5 Gy as a single dose from a Co-60 Theratron 780-C Teletherapy machine with energy of $1.25 \mathrm{MeV}$, in addition to a sham injection of normal saline at an average of $0.04 \mathrm{ml} / \mathrm{rat}$ per day, for 2 days preceding the irradiation.

Group $C(n=6)$ : the animals were randomized to receive 2.5 Gy of gamma-rays as a single dose from the same machine after pre-treatment with Dexamethasone, at $1 \mathrm{mg} / \mathrm{kg}$ daily, for 2 days preceding the irradiation.

Dexamethasone Preparation and Administration. Standard preparation of $1 \mathrm{ml}$ ampoules containing $4 \mathrm{mg}$ of dexamethasone (Huaughan, China, batch 050617) was administered via a sterile hypodermic syringe, with 28 gauge needle at a dose of $1 \mathrm{mg} / \mathrm{kg}$ body weight/day intraperitoneally once daily for 2 days, the last dose was given 1 hour before irradiation was delivered. The dose of dexamethasone was chosen based on other studies (Malomo et al., 2005).

Irradiation Procedure. Each experimental rat was administered with Ketamine hydrochloride injection (Rotex medica, Trittau, Germany, batch 40092 ) at $10 \mathrm{mg} / \mathrm{kg}$ body weight and Diazepam injection (Roche, Switzerland ) at 3mg/ $\mathrm{kg}$ body weight, both drugs intraperitoneally. This was for the purpose of sedation to immobilize the rats, thus ensuring an even distribution of radiation. Each rat was then strapped in a prone position in a specially designed plank and then fixed to the plank from the neck, trunk and tail using cotton strapping. The upper and lower limbs were fixed with cotton ropes though perforations in the plank to prevent struggling movement. Each 
experimental animal then received irradiation as a single fraction of 2.5 Gy of gamma-rays obtained from Cobalt-60 source. Irradiation was delivered by an AECL Theratron 780$\mathrm{C}$ Teletherapy machine with energy of $1.25 \mathrm{MeV}$, 'Theratron $780-C$ ' machine at a depth of $2.5 \mathrm{~cm}$, and a field size of $10 \mathrm{~cm}$ by $10 \mathrm{~cm}$, at the Radiotherapy Department of the University College Hospital, Ibadan. The radiation exposure time was three minutes. Renal shielding was not used.

Tissue Extraction, Processing and Histology. Immediately after irradiation, the rats were freed, placed in their cages, and transferred back to the laboratory where they were allowed to recover from anaesthesia. The animals were monitored till the $14^{\text {th }}$ day post-irradiation, when they were sacrificed. A laparotomy was then performed on each animal to expose the abdominal visceral and the gut displaced to reveal the retroperitoneal and posteriorly situated kidneys. The kidneys were carefully dissected out, extracted, rinsed in $10 \%$ formalin and then fixed immediately in $10 \%$ formalin.

Parameters studied. The fixed kidneys were then processed with routine paraffin wax techniques. Serial sections of $4 \mu \mathrm{m}$ thickness were made using a rotary microtome (Leitzer Wetzler). The sections were then stained using Haematoxylin and Eosin (H\&E) solution.

Using light microscope with an eyepiece objective ruler (Leitz, Germany), which was calibrated with a $2 \mathrm{~mm}$ stage micrometer (Leitz, Germany) at X 400 magnification. The following parameters were studied:
1. The maximum glomerular diameter.

2. The maximum width of glomerular space diameter in 20 randomly selected glomeruli in each slide of different animals.

3. The glomerular tuft cellularity was estimated by counting the total number of cells in 20 randomly selected glomeruli at X 400 magnification (Jimoh, 2003).

The mean value was determined in each case.

Data analysis. Values were expressed as mean \pm SD. The statistical significance of the mean differences between groups was assessed by Student's t Test. A p-value $(<0.05)$ was regarded as significant.

\section{RESULTS}

General observations. All animals that were irradiated became lethargic and became unresponsive to stimuli even after the anesthetic effect waned off. On the second day post-irradiation they all developed profuse diarrhoea that lasted between 24 to 48 hours.

Gross morphometry. Table I shows that all animals that received irradiation suffered weight loss on the $14^{\text {th }}$ day, which was the end of the experiment. The body weights of the control animals $(185.00 \pm 5.18 \mathrm{~g})$ were greater than those of animals that received irradiation only $(174.83 \pm 6.08 \mathrm{~g})$. This

Table I. Quantitative measurements of parameters in Control (Group A) and Radiation only (Group B).

\begin{tabular}{lcccc}
\multicolumn{1}{c}{ Variable } & n & $\begin{array}{c}\text { Control (Group A) } \\
\text { (mean } \pm \text { SD) }\end{array}$ & $\begin{array}{c}\text { Radiation only } \\
\text { (Group B) } \\
(\text { mean } \pm \text { SD) }\end{array}$ & p-value \\
Body weights $(\mathrm{g})$ on day 1 of experiment & 6 & $183.33 \pm 6.28$ & $181.33 \pm 7.12$ & 0.62 \\
Body weights $(\mathrm{g})$ on day 14 of experiment & 6 & $185.00 \pm 5.18$ & $174.83 \pm 6.08$ & 0.01 \\
Glomerular tuft cellularity $(\mu \mathrm{m})$ & 20 & $37.65 \pm 7.83$ & $41.45 \pm 6.01$ & 0.09 \\
Maximal glomerular diameter $(\mu \mathrm{m})$ & 20 & $42.00 \pm 3.08$ & $44.60 \pm 5.43$ & 0.07 \\
Maximum width of glomerular capsule $(\mu \mathrm{m})$ & 20 & $53.12 \pm 4.05$ & $59.08 \pm 8.3$ & 0.01
\end{tabular}

Table II. Quantitative measurements of parameters in Radiation only (Group B) and Radiation + Dexamethasone (Group C).

\begin{tabular}{|c|c|c|c|c|}
\hline Variable & $\mathbf{n}$ & $\begin{array}{c}\text { Radiation only } \\
\text { (Group B) } \\
(\text { mean } \pm \text { SD) }\end{array}$ & $\begin{array}{c}\text { Radiation }+ \\
\text { Dexamethasone } \\
(\text { Group C })(\text { mean } \pm \text { SD })\end{array}$ & p-value \\
\hline Body weights (g) on day 1 of experiment & 6 & $181.33 \pm 7.12$ & $186.67 \pm 4.68$ & 0.16 \\
\hline Body weights (g) on day 14 of experiment & 6 & $174.83 \pm 6.08$ & $176.00 \pm 3.29$ & 0.69 \\
\hline Glomerular tuft cellularity $(\mu \mathrm{m})$ & 20 & $41.45 \pm 6.01$ & $38.75 \pm 5.30$ & 0.14 \\
\hline Maximal glomerular diameter $(\mu \mathrm{m})$ & 20 & $44.60 \pm 5.43$ & $51.99 \pm 7.29$ & 0.00 \\
\hline Maximum width of glomerular capsule ( $\mu \mathrm{m})$ & 20 & $59.08 \pm 8.31$ & $59.93 \pm 6.39$ & 0.72 \\
\hline
\end{tabular}


was statistically significant $(\mathrm{p}=0.011)$. Similarly, irradiated animals that were treated with dexamethasone also recorded weight loss $(176.00 \pm 3.299 \mathrm{~g})$ when compared with control $(185.00 \pm 5.18 \mathrm{~g})$ which was also significant $(\mathrm{p}=0.005)$, as shown in Table III.

Histomorphometry. The slight increases in glomerular tuft cellularlity in the kidneys of the irradiated animals were not statistically significant.

Table I shows that the maximum width of the glomerular capsule was greater in the radiation only group $(59.08 \pm 8.31 \mu \mathrm{m})$ than the control $(53.12 \pm 4.05 \mu \mathrm{m})$ and this was significant $(\mathrm{p}=0.006)$. Also the maximum width of glomerular capsule of the radiation + dexamethasone animals was greater $(59.93 \pm 6.39 \mu \mathrm{m})$ than the control rats $(53.12 \pm$ $4.05 \mu \mathrm{m})$ which also was statistically significant ( $\mathrm{p}=0.000)$, as Table III shows.

Table II shows that the maximal glomerular diameter of the radiation + dexamethosone animals was greater (51.99 $\pm 7.29 \mu \mathrm{m})$ than those of radiation only group $(44.60 \pm 5.43$ $\mu \mathrm{m})$ and this was significant $(\mathrm{p}=0.001)$. Similarly, Table III shows that the maximal glomerular diameter of the kidneys of radiation + dexamethasone animals was greater $(51.99 \pm$ $7.29 \mu \mathrm{m})$ than the control animals $(42.00 \pm 3.08 \mu \mathrm{m})$, which is statistically significant $(\mathrm{p}=0.000)$.

The paired sample T-test shows in Table IV, that the maximal glomerular diameter was greater in the radiation + dexamethasone animals $(51.99 \pm 7.29 \mu \mathrm{m})$ than in both the control $(42.00 \pm 3.08 \mu \mathrm{m})$ and in the radiation only animals $(42.60 \pm 5.43 \mu \mathrm{m})$. Both results were significant with $\mathrm{p}$ values 0.000 , and 0.003 respectfully.

Table $\mathrm{V}$ shows that the maximum width of glomerular capsule in the radiation + dexamethasone animals was greater $(59.93 \pm 6.39 \mu \mathrm{m})$ than in the control $(53.12 \pm 4.05 \mu \mathrm{m})$. This was statistically significant $(\mathrm{p}=0.001)$. Similarly, Table 5 also shows that this same parameter was greater in the radiation only animals $(59.08 \pm 8.31 \mu \mathrm{m})$ than in the control $(53.12 \pm 4.05 \mu \mathrm{m})$, which was also significant $(\mathrm{p}=0.015)$.

Table III. Quantitative measurements of parameters in Control (Group A) and Radiation + Dexamethasone (Group C) groups.

$\begin{array}{lccrr}\text { Variable } & \text { n } & \begin{array}{c}\text { Control } \\ \text { (Group A) } \\ (\text { mean } \pm \text { SD) }\end{array} & \begin{array}{c}\text { Radiation + } \\ \text { Dexamethasone } \\ \text { (Group C) }\end{array} & \begin{array}{c}\text { p-value } \\ \text { Body weights }(\mathrm{g}) \text { on day 1 of experiment }\end{array} \\ \text { Body weights }(\mathrm{g}) \text { on day 14 of experiment } & 6 & 183.33 \pm 6.28 & 186.67 \pm 4.68 & 0.32 \\ \text { Glomerular tuft cellularity }(\mu \mathrm{m}) & 6 & 185.00 \pm 5.18 & 176.00 \pm 3.29 & 0.01 \\ \text { Maximal glomerular diameter }(\mu \mathrm{m}) & 20 & 37.65 \pm 7.83 & 38.75 \pm 5.30 & 0.61 \\ \text { Maximum width of glomerular capsule }(\mu \mathrm{m}) & 20 & 42.00 \pm 3.08 & 51.99 \pm 7.29 & 0.00 \\ & 20 & 53.12 \pm 4.05 & 59.93 \pm 6.39 & 0.00\end{array}$

Table IV. Paired sample t-test comparing the mean of maximal glomerular diameter in micrometer on Day 14.

\begin{tabular}{lccccc} 
Pairing & Group & n & Mean & SD & p-value \\
\hline Pair 1 & A & 20 & 42.00 & 3.08 & 0.08 \\
\multirow{2}{*}{ Pair 2 } & B & 20 & 44.60 & 5.43 & \\
& A & 20 & 42.00 & 3.08 & 0.00 \\
Pair 3 & C & 20 & 51.99 & 7.29 & \\
& B & 20 & 42.60 & 5.43 & 0.00
\end{tabular}

Table V. Paired sample t-test comparing the mean of maximum width of Bowman's capsule in micrometer on day 14 .

\begin{tabular}{llllll} 
Pairing & Group & n & Mean & SD & p-value \\
\hline Pair 1 & A & 20 & 53.12 & 4.05 & 0.02 \\
& B & 20 & 59.08 & 8.31 & \\
Pair 2 & A & 20 & 53.12 & 4.05 & 0.00 \\
& C & 20 & 59.93 & 6.39 & \\
Pair 3 & B & 20 & 59.08 & 8.31 & 0.67 \\
& C & 20 & 59.93 & 6.39 &
\end{tabular}

\section{DISCUSSION}

The kidney's major function is the maintenance of the body's osmotic and chemical homeostasis, a derangement of which causes renal impairment, leading to renal failure if left untreated.

Medically, ionizing radiation is an important modality in the management of neoplasia of different organs of the body, as in cancer of the breast, cervix, bones, kidneys, lung, among others. Radiation may also be applied as total body irradiation (TBI) in the preparation of patients as part of the conditioning regime before bone marrow transplantation. Radiation nephritis may be a side-effect presenting later after an initial 
latent period, causing the affected kidneys to become swollen and edematous.

The pathophysiology of radiation nephritis is due to cellular injury caused by ionizing radiation. All components of the kidneys are affected, including glomeruli, mesangium, blood vessels, tubular epithelium, and interstitium. Cohen explains that renal injury caused by ionizing radiation is initiated by oxidative injury to deoxyribonucleic acid (DNA), that is, it is a genotoxic injury. It is established that tissue injury elicits acute inflammation whose features among others include swelling of the affected part. This is due to accumulation of exudates particularly fluid, proteins, and cells from local vessels unto the damaged part (Stevens \& Lowe, 2000). Anti-inflammatory agents, like dexamethasone will be expected to ameliorate these features of acute inflammation

Tables I and II show weight losses recorded in all irradiated animals on the $14^{\text {th }}$ day of the experiment. The diarrhoea exhibited by all irradiated animals was most probably due to acute radiation injury to the continuously cycling cells (enterocytes) lining their intestinal tracts, causing them to lose their water-retention capability. Actively dividing cells are known to be extremely sensitive to radiation (Schull). The fluid loss from the diarrhoea must have contributed to the weight loss recorded in all the irradiated animals. The noted weight losses were statistically significant $(\mathrm{p}<0.05)$. The radiation plus dexamethasone treated group of animals did not enjoy any protection as they too suffered diarrhoea like the radiation only group. This suggests the failure of dexamethasone to protect the intestinal mucosa from the assault of radiation injury.

Tables I, II and III show evidences of swelling of the glomeruli in all the irradiated animals as observation of increases in the measurements recorded both of maximal glomerular diameter and maximum width of glomerular capsule were noted. The results of Table III, particularly showed these two parameters were higher in the irradiated plus dexamethasone treated groups, which was statistically significant $(\mathrm{p}<0.05)$. The anticipated protection of dexamethasone on the radiation injury suffered by the kidneys was not observed.

The hypercellularity in kidneys especially in inflammatory conditions are associated with an increase in cell number linked to cellular proliferation of mesangial, endothelial or parietal epithelium cells. In this study, no significant association existed between irradiated animals that received dexamethasone treatment and irradiated animals that did not receive dexamethasone, when glomerular tuft cellularity was considered as a variable. Table II shows that the slight differences observed were not statistically significant.

Dexamethasone was not beneficial in these groups as it did not ameliorate the renal injury represented by the glomerular swelling. This implies that dexamethasone was unable to mitigate the effects of radiation injury in the kidneys, especially at the experimental dose we gave the animals. Tada et al. (1997) had reported that dexamethasone treatment may have an anti-oedema effect and also modify subsequent development of vascular and inflammatory changes in neural tissues, we have not demonstrated this in the renal tissue used in this study.

Cohen explains that renal injury caused by ionizing radiation is initiated by oxidative injury to deoxyribonucleic acid (DNA), that is, it is a genotoxic injury. This may thus explain why dexamethasone was unable to reduce the effect of the injury caused by irradiation, possible reasons being that (a): the physiologic dose of dexamethasone used in this experiment might have been insufficient to mitigate the effects of this ionizing renal injury; (b) since the ionizing damage occurs in the DNA within the nucleus, the membrane stabilizing function of glucocorticoids might have been rendered ineffective. This is possible since the function of dexamethasone, like other steroids involves cytoplasmic receptors. The receptors are largely DNA-binding proteins and therefore regulate transcription of specific genes, ultimately resulting in protein synthesis (Levitzki, 1991). Radiation damage to the nuclear DNA will potentially incapacitate steroid function as functional proteins may not be formed; (c) the damaging effect of direct radiation might have overwhelmed the protective anti-inflammatory potentials of dexamethasone, thereby masking any ameliorative activity it could have exhibited especially at the physiologic dosage we used in this study.

In conclusion, pre-irradiation administration of $1 \mathrm{mg} /$ $\mathrm{kg}$ of $4 \mathrm{mg} / \mathrm{ml}$ standard preparation of dexamethasone, administered intraperitoneally, did not prevent weight loss, nor ameliorate the swelling of glomeruli caused by radiation injury 2 weeks post-irradiation. Dexamethasone, though a strong anti-inflammatory agent, did not offer any noticeable anti-inflammatory protection from radiation injury, at this dosage and level of this study.

\section{ACKNOWLEDGEMENTS}

We appreciate Mrs B. O. Akinlade and Mrs A. O. Ekisola of the Department of Radiotherapy, University College Hospital, Ibadan, for their helpful roles in the irradiation procedures. 
OWOEYE, O.; MALOMO, A. O.; ELUMELU, T. N.; SALAMI,A. A.; OSUAGWU, F. C.; AKINLOLU, A. A.; ADENIPEKUN, A. \& SHOKUNBI, M. T. Nefritis por radiación: Efecto anti-inflamatorio de la dexametasona en ratas Wistar adultas (Rattus norvegicus). Int. J. Morphol., 26(1):69-74, 2008.

RESUMEN: Fue estudiado el efecto anti-inflamatorio de la dexametasona en riñones irradiados de 18 ratas Wistar adultas (Rattus norvegicus). Luego de la aclimatización, aleatoriamente se dividieron en 3 grupos de 6 animales por grupo. El grupo control recibió una solución salina normal, sin recibir drogas ni radiación. El segundo grupo recibió solución salina normal y radiación. El tercer grupo recibió tratamiento previo con dexametasona con $1 \mathrm{mg} / \mathrm{kg}$ de peso corporal / día, durante 2 días, seguido de radiación. Los animales fueron expuestos a radiación con una fracción independiente de 2.5 Gy de rayos gamma por una fuente de Cobalto-60, usando una máquina de teleterapia AECL Theatron 780-C. Después de la exposición a las diferentes intervenciones, los animales fueron sacrificados el día 14 post-irradiación y los riñones de cada uno de los animales fueron disecados. Los tejidos renales fueron sometidos a procesamiento histológico, y luego se estudiaron utilizando un objetivo ocular milimetrado calibrado a $2 \mathrm{~mm}$ para el estudio histomorfométrico. Se demostró que todos los animales irradiados sufrieron pérdida de peso 14 días después de ésta ( $\mathrm{p}<0.05)$, independientemente de los tratamientos adicionales con dexametasona, siendo estadísticamente significativo. La histomorfometría mostró que el ancho máximo de la cápsula glomerular fue significativamente mayor en los grupos irradiados que en el control en $\mathrm{p}<0.05$. El diámetro máximo del glomérulo fue significativamente mayor en los animales irradiados en comparación con los animales control p $<0.05$. Los resultados de este estudio mostraron que la administración intraperitoneal, de $1 \mathrm{mg} / \mathrm{kg}$ de peso corporal / día durante 2 días, de dexametasona antes de comenzar el tratamiento con irradiación, no impide la pérdida de peso ni permite aliviar el edema de los nefrones, injuria producto de la radiación a las Ratas Wistar.

PALABRAS CLAVE: Radiación; Nefrones; Glomérulo; nefritis; Anti-inflamatorio; Riñon.

\section{REFERENCES}

Aunapuu, M.; Pekhter, I.; Roosaar, P.; Gershkevich, E.; Mar'iamiagi, M. M.; Arend, A.; Kol'ts, I. \& Ots, M. Morphological changes in the kidney nephrectomy and low-dose radiation. Tsitologia, 45(6):555-63, 2003.

Cohen, E. P. Nephritis, Radiation. Medicine Journal, 3(3):1-20, 2002.

Cohen, E. P.; Fish, B. L. \& Moulder, J. E. Successful brief captopril treatment in experimental radiation nephropathy. J. Lab. Clin. Med., 129(5):536-47, 1997.

Ganong, W. F. Revision of Medical Physiology. 20 ${ }^{\text {th }}$ ed. California, McGraw-Hill, 2001. pp. 358-9.

Guyton, A. C. \& Hall, J. E. Textbook of Medical Physiology. $10^{\text {th }}$ Ed. Philadelphia, WB Saunders Company, 2000. pp 875-9.

Haynes, R. C. Jr. Adrenocorticotropic hormone; adrenocortical steroids and their synthetic analogs; inhibitors of the synthesis and actions of adrenocortical hormones. Goodman \& Gilman's 'Pharmacological basis of therapeutics', $8^{\text {th }}$ ed. New York, McGraw-Hill, 1992. pp. 1431-61

Jimoh, S. A. Combined effect of Cisplatin therapy and analgesics administration of the Wistar rat kidney. M. Sc Anatomy thesis, Ibadan University of Ibadan, Nigeria, 2003.

Levitzki, A. Cell Signalling. Encyclopaedia of Human Biology. $2^{\text {nd }}$ ed. San Diego, Academic Press, 1991. V. 2. pp. 561-71.

Malomo, A. O.; Owoeye, O.; Elumelu, T. N.; Akang, E. E.; Adenipekun, A.; Campbell, O. B. \& Shokunbi, M. T. The effect of dexamethasone, metronidazole, and ascorbic acid on the morphological changes induced by gamma rays on the spinal cord of Wistar rat. Afr. J. Med. Med. Sci., 34(2):161-5, 2005.
Moulder, J. E.; Fish, B. L. \& Cohen, E. P. Treatment of radiation nephropathy with ACE inhibitors. Int. J. Radiat. Oncol. Biol. Phys., 27(1):93-9, 1993.

Salako, B.L. The relationship between kidney and hypertension: a review. Afr. J. Med. Med. Sci., 34(4):335-40, 2005.

Schull, W. J. Effects of atomic radiation. New York, Wiley-Liss Publishers, 1995. p35.

Stevens, A. \& Lowe, J. S. Human Histology. $2^{\text {nd }}$ ed. London, Mosby, 1999. pp 78, 358.

Stevens, A. \& Lowe, J. Pathology, $2^{\text {nd }}$ ed. Edinburgh, Mosby, 2000. pp 35-50.

Tada, E.; Matsumoto, K.; Kinoshita, K.; Furuta, T. \& Ohmoto, T. The protective effect of dexamethasone against radiation damage by interstitial irradiation in normal monkey brain. Neurosurgery, 4(1):209-17, 1997.

Verheij, M.; Stewart, F. A.; Oussoren, Y.; Weening, J. J. \& Dewit, L. Amelioration of radiation nephropathy by acetylsalicylic acid. Int. J. Radiat. Biol., 67(5):587-96, 1995.

Young, B. \& Heath, J. W. Wheater's Functional Histology- a text and colour atlas. $4^{\text {th }}$ ed. Edinburgh, Churchill Livingstone, 2000. pp 118, 155, 164, 373.

Correspondence to:

Dr. Olatunde Owoeye

Department of Anatomy

College of Medicine

University of Ibadan

NIGERIA

E-mail: oowoeye2001@yahoo.com

Received: 25-05-2007 Accepted: 26-11-2007 